\title{
Differentially expressed stress-related genes in the compatible citrus-Citrus leprosis virus interaction
}

\author{
Juliana Freitas-Astúa ${ }^{1,2}$, Marinês Bastianel ${ }^{1}$, Eliane C. Locali-Fabris ${ }^{1}$, Valdenice M. Novelli ${ }^{1}$, \\ Ana Carla Silva-Pinhati ${ }^{1}$, Ana Carolina Basílio-Palmieri ${ }^{1}$, Maria Luisa P.N. Targon ${ }^{1}$ \\ and Marcos A. Machado \\ ${ }^{1}$ Centro APTA Citros Sylvio Moreira, Instituto Agronômico de Campinas, Cordeirópolis, SP, Brazil. \\ ${ }^{2}$ Embrapa Mandioca e Fruticultura Tropical, Cruz das Almas, BA, Brazil.
}

\begin{abstract}
Leprosis, caused by Citrus leprosis virus, cytoplasmic type (CiLV-C), is the main viral disease in the Brazilian citrus industry. This occurs because of the widespread source of inoculum and the year-round presence of the vector, the tenuipalpid mite Brevipalpus phoenicis, in citrus plants. In addition, while some Citrus species are resistant to CiLV-C, $C$. sinensis, the main cultivated species in the country, is extremely susceptible to the disease. The main objective of this work was to identify genes in $C$. sinensis cv. Pêra plants that were differentially expressed after the host was challenged with CiLV-C. In order to accomplish that, CDNA libraries were constructed from healthy and CiLV-inoculated sweet orange leaves. Two hundred and fifty-four genes were found to differ significantly in terms of expression, with 193 of them induced and 61 repressed after inoculation. Here we discuss the possible roles of a sub-set of these genes involved in metabolism, energy, signaling and cell rescue, defense and virulence, and indicate which kind of response may take place in the initial steps of the disease. Although the symptoms induced by CiLV-C in its compatible interaction with sweet orange resemble those of hypersensitive response (HR) in incompatible interactions, our data indicate that, apparently, the manifestation of leprosis symptoms should not be considered HR.
\end{abstract}

Key words: EST, disease, CiLV, in silico hybridization, sweet orange, Citrus sinensis.

Received: October 20, 2006; Accepted: May 14, 2007.

\section{Introduction}

The citrus industry is one of most important agribusinesses in Brazil, with exports of concentrated juice representing $80 \%$ of the world market (Boteon and Neves, 2005). However, Brazilian average productivity is very low due to drought problems, associated with various pathogens that affect the crop. Citrus leprosis virus, cytoplasmic type (CiLV-C) has been considered the main citrus viral pathogen in Brazil for the last several years. Its importance has significantly increased in other countries as well, since it is now present in most South and Central American countries, and has reached the South of Mexico (Bastianel et al., 2006a).

Even though the disease has been known for decades, only recently important progress has been made in understanding its etiology and interactions. Leprosis is a very complex pathosystem involving the causal virus, the Brevipalpus mite vector, the susceptible Citrus plant and, possibly, an endosymbiont (Novelli et al., 2005).

Send correspondence to Juliana Freitas-Astúa. Centro APTA Citros Sylvio Moreira, Instituto Agronômico de Campinas, Rodovia Anhangüera km158, Caixa Postal 4, 13490-970 Cordeirópolis, SP, Brazil. E-mail: jfastua@centrodecitricultura.br.
CiLV-C presents morphological - but no sequence similarity with rhabdoviruses (Locali-Fabris et al., 2006; Pascon et al., 2006). It is transmitted by a tenuipalpid mite, and induces only local lesions in its susceptible hosts (Bastianel et al., 2006a). Because of its unique properties, it has been proposed as a type member of a new virus genus named Cilevirus (Locali-Fabris et al., 2006).

Typical leprosis symptoms include chlorotic and/ or necrotic local lesions in stems, fruits, and leaves of susceptible hosts. These lesions can coalesce, cause dieback and even the death of young plants, but the virus does not invade the plant systemically (Bastianel et al., 2006a). For years, it has been known that sweet oranges (Citrus sinensis) are more susceptible to leprosis than mandarins (C. reshni, C. reticulata), lemons (C. limon), limes $(C$. aurantifolia), and citrus hybrids (Bastianel et al., 2006a). However, only recently the genetics of the disease is starting to be understood. Bastianel et al. (2006b) have suggested that one or few major genes are related to leprosis resistance in Murcott tangor (a hybrid between sweet orange and mandarin).

It is known that plants respond in a complex way to biotic and abiotic stresses. However, few studies have tried 
to elucidate their response to complex pathosystems, especially when viral agents are involved. Compatible responses of sweet oranges to CiLV-C macroscopically resemble those of a hypersensitive response (HR) observed in resistant genotypes to some bacteria and viruses, but with a significant delay in symptom appearance. While HR is often visible after several hours or few days from pathogen challenge, symptoms of leprosis in citrus are evident only weeks after CiLV-C inoculation (Bastianel et al., 2006a). It is not known, however, whether or not the response to CiLV-C resembles that of incompatible interactions at the molecular level.

Information derived from EST (expressed sequence tags) sequencing can help unravel the reason why some citrus species or hybrids are resistant or tolerant to the disease while others are susceptible, through their differential gene expression profiles. Also, through the comparison of differential gene expression between susceptible plants prior and after inoculation, it is possible to draw conclusions regarding how a particular species or variety behaves in response to the virus.

This work is the first attempt to better understand the initial steps that will lead to the appearance of leprosis symptoms in citrus through the comparison of gene expression patterns of $C$. sinensis inoculated and non-inoculated with CiLV-C.

Several transcripts involved in stress response were up- or down-regulated in CiLV-C challenged plants when in silico compared to the non-inoculated ones, and they provide valuable information for understanding the initial steps of infection in this compatible interaction. However, other categories of genes were found as well. A high number of transcripts involved in plant metabolism was found to be differentially expressed in our libraries. This is not a surprise, since virus infections frequently have dramatic effects on plant metabolism, affecting a variety of essential cellular processes such as synthesis of nucleic acids and proteins, lipids and carbohydrates metabolism, and hormone and enzyme functions (Hull, 2002). Nevertheless, some of the findings differed from those reported either for systemic viral infections or viral-induced HR, and will be discussed below.

\section{Materials and Methods}

\section{Construction of cDNA libraries}

Two cDNA libraries were constructed from mRNA isolated from leaves of Pêra sweet orange $(C$. sinensis $\mathrm{L}$. Osbeck) grafted on Rangpur lime (C. limonia Osbeck). One of them was constructed from non-inoculated leaves and served as a mock control library. The other one was prepared from leaves collected $48 \mathrm{~h}$ after CiLV-C inoculation by viruliferous Brevipalpus phoenicis mites. The presence of the virus in the mites was confirmed in a sub-set of vector population by RT-PCR as described by Locali et al. (2003) with modifications (Freitas-Astúa et al. unpublished data). Details about RNA extraction, cDNA libraries construction and sequencing can be found in Targon et al. (this issue).

\section{Database analyses}

Reads from the two libraries were clusterized using the CAP3 tool (Huang and Madan, 1999), with default parameters. For each assembled tentative consensus (TC), the relative abundance of transcripts was calculated, using a correction factor of 10,000 for normalizing, and the significance was given by using the methodology described in Audic and Claverie (1997) for two libraries, with a threshold of p-value $\leq 0.05$. The TCs were automatically compared, through BlastX algorithm, to sequences available in the public databases GenBank (http://www.ncbi.nlm.nih. gov/BLAST/), Arabidopsis Genome Initiative dataset (http://www.arabidopsis.org/), and KEGG (Kyoto Encyclopedia of Genes and Genomes - http://www.genome. $\mathrm{jp} / \mathrm{kegg} /$ ). TCs that yielded hits with e-values lower than $\mathrm{e}^{-10}$ were categorized using the Munich Center for Proteins and Sequences Functional Categories (MIPS FunCat) v. 1.3 (http://mips.gsf.de). When the TCs were automatically classified into the 98 (classification not yet clear cut) or 99 (unclassified protein) classes, an additional manual categorization was performed. More details on the bioinformatic analyses can be found in Reis et al. (this issue).

\section{Results and Discussion}

cDNA libraries were constructed from healthy and CiLV-C inoculated sweet orange leaves. They yielded 9,536 and 5,664 reads (8,188 and 4,852 valid reads), respectively, that were clusterized in TCs. Using an in silico hybridization strategy, 254 of those putative genes were found to be differentially expressed, with 193 of them induced and 61 repressed by the pathogen, and distributed within 19 categories classified according to the MIPS FunCat (Table 1). This large number of categories observed was expected since, in compatible hosts, viral invasion triggers numerous biochemical and physiological changes in cells, tissues, and even whole plants, causing significant changes in host gene expression (Moller and Chua, 1999; Maule et al., 2002; Huang et al., 2005). A subset of such categories was chosen to be studied in details due to their involvement in stress responses. They included, in addition to genes involved in cell rescue, defense and virulence, those involved in cellular communication/signal transduction mechanisms, metabolism, and energy.

\section{Signaling and cell rescue, defense and virulence}

All of the five TCs composed of reads related to cellular communication/signal transduction mechanisms that were differentially expressed in our two conditions (comprising genes that code for glycoproteins, lectin, cyclophillin and calcium ion binding proteins) were induced 
Table 1 - Categorization of differentially expressed transcripts in CiLV-C inoculated Citrus sinensis leaves according to Munich Center for Proteins and Sequences Functional Categories (MIPS).

\begin{tabular}{|c|c|c|c|}
\hline Number & MIPS FunCat & $\begin{array}{l}\text { Number of repressed } \\
\text { transcripts }\end{array}$ & $\begin{array}{c}\text { Number of induced } \\
\text { transcripts }\end{array}$ \\
\hline 1 & Metabolism & 26 & 28 \\
\hline 2 & Energy & 11 & 8 \\
\hline 3 & Cell cycle and DNA processing & 1 & 4 \\
\hline 4 & Transcription & 0 & 7 \\
\hline 5 & Protein synthesis & 1 & 4 \\
\hline 6 & Protein fate (folding, modification, destination) & 2 & 12 \\
\hline 10 & Cellular communication/signal transduction mechanism & 0 & 5 \\
\hline 11 & Cell rescue, defense and virulence & 5 & 15 \\
\hline 13 & Regulation of / interaction with cellular environment & 0 & 4 \\
\hline 14 & Cell fate & 0 & 6 \\
\hline 20 & Systemic regulation of / interaction with environment & 0 & 4 \\
\hline 25 & Development (systemic) & 0 & 2 \\
\hline 30 & Control of cellular organization & 0 & 6 \\
\hline 33 & Cell type differentiation & 0 & 1 \\
\hline 40 & Subcellular localisation & 5 & 11 \\
\hline 43 & Cell type localisation & 0 & 1 \\
\hline 63 & Protein with binding function or cofactor requirement (structural or catalytic) & 4 & 16 \\
\hline 67 & Transport facilitation & 3 & 8 \\
\hline \multirow[t]{2}{*}{99} & Unclassified proteins & 3 & 51 \\
\hline & Total & 61 & 193 \\
\hline
\end{tabular}

after the CiLV-C challenge in the citrus plants. This may be due to their role in triggering downstream processes that will result in the compatible interaction (= disease). At least three of these transcripts have been also related to defense against biotic stressors such as insects [lectin (Gatehouse et al., 1999)], pathogens [cyclophillin (Romano et al., 2004) and calcium ion binding protein (Chiasson et al., 2005)]. Particularly for calcium ion binding proteins, their role in defense has been strongly associated with the occurrence of $\mathrm{HR}$, since these proteins regulate downstream targets as part of a coordinated cellular response to a given stimulus (Chiasson et al., 2005). It should be noted that the symptoms induced by CiLV-C in its compatible interaction with sweet orange resemble those of HR in incompatible interactions, and at first glance it appeared that similar responses would occur in both situations. However, with few exceptions, such as the induction of calcium ion binding protein genes, other aspects of the interactions are completely distinct and will be discussed throughout this manuscript.

Within the rescue, defense and virulence functional category, our data revealed five and 15 TCs harboring transcripts that were, respectively, down- and up-regulated during virus infection. Amongst the induced genes, those that code for a prolin rich protein, a cytochrome P450, a Lea5, a catalase, a miraculin, a gluthatione reductase, a hsp20, a superoxide dismutase, a metallothionein, and a zing finger protein (Table 2) can be highlighted.
Even though they can be important in biotic and abiotic stress responses, their role in our compatible pathosystem does not seem to be pivotal. The oxidative burst may play the role of an internal emergency signal for induction of the metabolic cascade for active defense (Doke et al., 1996). The activation of antioxidant enzymes as mechanism of cellular protection is commonly observed in plants in response to pathogens, and is one of the first defense responses activated that may be responsible for triggering the beginning of HR (Grant and Loake, 2000). These authors report the isolation of a transcript that presented similarity with the enzyme superoxide dismutase (SOD). This enzyme is responsible for the synthesis of hydrogen peroxide, toxic to microorganisms. Catalase protects cells from hydrogen peroxide which can be generated from an SOD catalyzed reaction.

A putative cytochrome $\mathrm{P} 450$ gene from Capsicum $\mathrm{sp}$. was identified using cDNA microarray analysis of gene expression following induction of HR by leaf inoculation with the non-host pathogen Xanthomonas axonopodis (Kim et al., 2006). This indicates that cytochrome P450 in pepper plants may play a role in the defense response pathways (Kim et al., 2006). However, even though we found genes that are often involved in HR to be induced in our infected library, it should be noted that they comprised a small number of the total transcripts related to HR (Guidetti-Gonzalez et al., this issue). 
Table 2 - Result of the BlastX search of induced and repressed C. sinensis genes after CiLV-C inoculation according to Arabidopsis thaliana GenBank data.

\begin{tabular}{|c|c|c|c|c|}
\hline Gene product - best BlastX hit & $\begin{array}{l}\text { Accession number } \\
\text { in GenBank }\end{array}$ & E-value & $\begin{array}{l}\text { Identities of } \\
\text { aminoacids }\end{array}$ & p-value \\
\hline \multicolumn{5}{|l|}{ Induced genes } \\
\hline \multicolumn{5}{|l|}{01 - Metabolism } \\
\hline Alpha-amylase [Malus x domestica $]$ & AAF63239.1 & 0.0 & $349 / 413(84 \%)$ & 0.0254 \\
\hline F1-ATPase gamma subunit [Ipomoea batatas] & BAA03526.1 & $\mathrm{e}^{-149}$ & $278 / 326(85 \%)$ & 0.0267 \\
\hline Lipoxygenase [Citrus jambhiri] & BAB84352.1 & 0.0 & $538 / 605(88 \%)$ & 0.0000 \\
\hline Nucleotide sugar epimerase-like protein [Arabidopsis thaliana] & AAM62729.1 & 0.0 & $375 / 425(88 \%)$ & 0.0007 \\
\hline Pyruvate kinase - like 2.7.1.40 & AAN46773.1 & $4 e^{-89}$ & $177 / 271(65 \%)$ & 0.0254 \\
\hline Putative AIM1 protein [Arabidopsis thaliana] & AAM20293.1 & $\mathrm{e}^{-178}$ & $311 / 410(75 \%)$ & 0.0254 \\
\hline Alcohol dehydrogenase [Solanum tuberosum] & CAA63093.1 & $3 e^{-99}$ & $177 / 292(60 \%)$ & 0.0254 \\
\hline PGPD14 protein $[$ Arabidopsis thaliana $]$ & BAB10613.1 & $3 e^{-43}$ & $77 / 113(68 \%)$ & 0.0254 \\
\hline Lectin - related protein precursor/ribosomal protein & AAM14955.1 & $2 \mathrm{e}^{-18}$ & $42 / 59(71 \%)$ & 0.0254 \\
\hline Lectin-related protein precursor [Citrus $x$ paradisi] & AAG38522.1 & $\mathrm{e}^{-151}$ & $268 / 268(100 \%)$ & 0.0000 \\
\hline Myo-inositol 1-phosphate synthase (Zea mays) & AAG40328.1 & $1 \mathrm{e}^{-11}$ & $70 / 218(32 \%)$ & 0.0115 \\
\hline Ketol-acid reductoisomerase (Arabidopsis thaliana) & AAN33197.1 & 0.0 & $495 / 591(83 \%)$ & 0.0254 \\
\hline Sucrose synthase (Arabidopsis thaliana) & NP_177480.1 & $3 \mathrm{e}^{-94}$ & $170 / 258(65 \%)$ & 0.0254 \\
\hline Thiolase family protein (Pseudomonas fluorescens) & YP_260048.1 & $6 e^{-86}$ & $158 / 181(87 \%)$ & 0.0254 \\
\hline Amino-alcoholphosphotransferase (Brassica rapa) & AAB53764.1 & $5 \mathrm{e}^{-76}$ & $132 / 162(81 \%)$ & 0.0254 \\
\hline Ribonucleotide reductase (Nicotiana tabacum) & CAA71816.1 & $\mathrm{e}^{-177}$ & $302 / 344(87 \%)$ & 0.0086 \\
\hline Putative pectinesterase (Arabidopsis thaliana) & AAM14264.1 & $\mathrm{e}^{-113}$ & 199/301 (66\%) & 0.0254 \\
\hline Putative glucose-6-phosphate isomerase (Oryza sativa) & XP_450926.1 & 0.0 & $357 / 433(82 \%)$ & 0.0254 \\
\hline Acyl-coenzyme A synthetases/AMP-(fatty) acid ligases (P. fluorescens) & ZP_00262534. & $\mathrm{e}^{-126}$ & $220 / 239(92 \%)$ & 0.0086 \\
\hline GMPase (Medicago sativa) & AAT58365.1 & 0.0 & $332 / 361(91 \%)$ & 0.0267 \\
\hline ADP, ATP carrier-like protein (Arabidopsis thaliana) & CAB79641.1 & $\mathrm{e}^{-177}$ & $310 / 378(82 \%)$ & 0.0238 \\
\hline Hydroxymethyltransferase (Arabidopsis thaliana) & AAM16248.1 & 0.0 & $426 / 471(90 \%)$ & 0.0284 \\
\hline Acidic class II chitinase (Citrus jambhiri) & BAC20285.1 & $\mathrm{e}^{-169}$ & $279 / 293(95 \%)$ & 0.0254 \\
\hline Ethylene-inducible protein & Q39963 & $\mathrm{e}^{-162}$ & $291 / 310(93 \%)$ & 0.0254 \\
\hline Acidic class I chitinase (Citrus jambhiri) & BAC20284.1 & $\mathrm{e}^{-163}$ & $270 / 301(89 \%)$ & 0.0000 \\
\hline Putative RNA-binding protein (Arabidopsis thaliana) & AAF21191.1 & $\mathrm{e}^{-111}$ & $204 / 300(68 \%)$ & 0.0254 \\
\hline Endo-1,4-beta-glucanase (Populus tremuloides) & AAT75041.1 & 0.0 & $543 / 620(87 \%)$ & 0.0086 \\
\hline \multicolumn{5}{|l|}{02 - Energy } \\
\hline $\begin{array}{l}\text { PSAD_NICSY Photosystem I reaction center subunit II, chloroplast precursor } \\
\text { [Nicotiana sylvestris] }\end{array}$ & CAA42623.1 & $2 \mathrm{e}^{-89}$ & $170 / 206(82 \%)$ & 0.0254 \\
\hline Chlorophyll A/B binding protein $[$ Prunus persica $]$ & AAC3498.3.1 & $\mathrm{e}^{-145}$ & $247 / 265(93 \%)$ & 0.0218 \\
\hline Chlorophyll a/b-binding protein $\mathrm{CP} 24$ precursor [Vigna radiata] & AAD27882.2 & $\mathrm{e}^{-127}$ & $217 / 258(84 \%)$ & 0.0115 \\
\hline Thylakoid lumenal $20 \mathrm{kDa}$ protein-like [Oryza sativa (japonica cultivar-group)] & BDA68170.1 & $3 e^{-86}$ & $132 / 165(80 \%)$ & 0.0029 \\
\hline Chlorophyll a/b-binding protein (cab-11) tomato & S14305 & $\mathrm{e}^{-127}$ & $219 / 250(87 \%)$ & 0.0120 \\
\hline Chloroplast oxygen-evolving enhancer protein [Manihot esculenta] & AAV74404.1 & $\mathrm{e}^{-91}$ & $177 / 237(74 \%)$ & 0.0045 \\
\hline $\begin{array}{l}23 \mathrm{kDa} \text { polypeptide of the oxygen-evolving complex of photosystem II } \\
\text { [Cucumis sativus] }\end{array}$ & BAA89317.1 & $\mathrm{e}^{-114}$ & $214 / 264(81 \%)$ & 0.0284 \\
\hline Unnamed protein product [Lycopersicon esculentum] & CAA32121.1 & $2 \mathrm{e}^{-67}$ & $129 / 170(75 \%)$ & 0.0096 \\
\hline \multicolumn{5}{|l|}{10 - Cellular Communication/signal transduction mechanism } \\
\hline SIEP 1L protein [Beta vulgaris] & CAA6158.1 & $4 e^{-80}$ & $150 / 225(66 \%)$ & 0.0086 \\
\hline Putative protein $[$ Arabidopsis thaliana $]$ & CAB80500.1 & $7 e^{-42}$ & $87 / 109(79 \%)$ & 0.0254 \\
\hline Lectin-related protein precursor [Citrus $x$ paradisi] & AAG3852.1 & $2 \mathrm{e}^{-65}$ & $148 / 276(53 \%)$ & 0.0115 \\
\hline Unknown protein $[$ Arabidopsis thaliana $]$ & AAM67515.1 & $\mathrm{e}^{-167}$ & $243 / 338(71 \%)$ & 0.0254 \\
\hline Putative cyclophilin [Lycopersicon esculentum] & AAW22880.1 & $2 e^{-87}$ & $162 / 210(77 \%)$ & 0.0086 \\
\hline
\end{tabular}


Table 2 (cont.)

\begin{tabular}{|c|c|c|c|c|}
\hline Gene product - best BlastX hit & $\begin{array}{l}\text { Accession number } \\
\text { in GenBank }\end{array}$ & E-value & $\begin{array}{l}\text { Identities of } \\
\text { aminoacids }\end{array}$ & p-value \\
\hline \multicolumn{5}{|l|}{11 - Cell rescue, defense and virulence } \\
\hline $\begin{array}{l}\text { Ozone-responsive stress-related protein-like [Oryza sativa (japonica } \\
\text { cultivar-group)] }\end{array}$ & NP910312.1 & $2 \mathrm{e}^{-28}$ & $59 / 75(78 \%)$ & 0.0029 \\
\hline Superoxide dismutase $[\mathrm{Mn}]$, mitochondrial precursor & P35017 & $\mathrm{e}^{-105}$ & $186 / 231(80 \%)$ & 0.0254 \\
\hline $\begin{array}{l}31.2 \mathrm{kDa} \text { small heat shock family protein / hsp20 family protein } \\
\text { [Arabidopsis thaliana] }\end{array}$ & NP172134.1 & $5 e^{-41}$ & $104 / 286(36 \%)$ & 0.0254 \\
\hline Glutathione reductase [Pisum sativum] & CAA66924.1 & 0.0 & $417 / 499(83 \%)$ & 0.0254 \\
\hline Proline-rich protein [Solanum tuberosum] & CAA04449.1 & $\mathrm{e}^{-100}$ & $219 / 472(46 \%)$ & 0.0115 \\
\hline P450 monooxygenase [Gossypium arboreum] & AAG34695.1 & $2 \mathrm{e}^{-72}$ & $131 / 276(47 \%)$ & 0.0254 \\
\hline Late-embryogenesis Lea 5 protein [Citrus sinensis] & CAA 86851.1 & $e^{-47}$ & $97 / 97(100 \%)$ & 0.0009 \\
\hline Catalase $[$ Prunus persica $]$ & CAD42909.1 & 0.0 & $409 / 493(82 \%)$ & 0.0395 \\
\hline Miraculin like protein 2 [Citrus $x$ paradisi] & AAG38518.1 & $\mathrm{e}^{-132}$ & $235 / 236(99 \%)$ & 0.0001 \\
\hline Putative nitrilase-associated protein [Arabidopsis thaliana] & AAM64577.1 & $2 \mathrm{e}^{-35}$ & $81 / 113(71 \%)$ & 0.0029 \\
\hline Zinc finger (AN1-like) family protein [Arabidopsis thaliana] & NP_566429.1 & $2 \mathrm{e}^{-45}$ & $99 / 176(56 \%)$ & 0.0254 \\
\hline Miraculin like protein $2[$ Citrus $x$ paradisi $]$ & AAG38518.1 & $3 e^{-60}$ & $127 / 222(57 \%)$ & 0.0086 \\
\hline $\begin{array}{l}\text { Pollen allergen-like protein [Datisca glomerata] pathogenesis-related protein } \\
\text { PR10A }\end{array}$ & CAD33532.1 & $5 \mathrm{e}^{-42}$ & $86 / 160(53 \%)$ & 0.0086 \\
\hline Metallothionein like protein [Citrus unshiu] & AAK08209.1 & $6 \mathrm{e}^{-35}$ & $67 / 68(98 \%)$ & 0.0029 \\
\hline Zing finger (C3HC4-type RING finger) family protein [Arabidopsis thaliana] & NP197938.2 & $\mathrm{e}^{-132}$ & $210 / 306(68 \%)$ & 0.0254 \\
\hline \multicolumn{5}{|l|}{ Repressed genes } \\
\hline \multicolumn{5}{|l|}{01 - Metabolism } \\
\hline Glutamyl-tRNA reductase 1(GluTR) [Cucumis sativus] & BAA08910.1 & 0.0 & $444 / 559(79 \%)$ & 0.0164 \\
\hline Aminotransferase 2 [Cucumis melo] & AAQ56195.1 & 0.0 & $360 / 401(89 \%)$ & 0.0048 \\
\hline Putative acyl CoA synthetase [Arabidopsis thaliana] & AAD43157.1 & $\mathrm{e}^{-159}$ & $270 / 421(64 \%)$ & 0.0372 \\
\hline $\begin{array}{l}\text { Short-chain dehydrogenase/reductase (SDR) family protein [Arabidopsis } \\
\text { thaliana] }\end{array}$ & NP_191681.1 & $2 \mathrm{e}^{-45}$ & $101 / 163(61 \%)$ & 0.0372 \\
\hline Glycine/ serine hydroxymethyltransferase [Solanum tuberosum $]$ & CAA81082.1 & 0.0 & $474 / 518(91 \%)$ & 0.0047 \\
\hline Phenylalanine-ammonia lyase [Citrus clementina $\mathrm{x}$ Citrus reticulata] & CAB42794.1 & 0.0 & $703 / 718(97 \%)$ & 0.0164 \\
\hline P-Protein precursor [Solanum tuberosum $]$ & CAB16918.1 & 0.0 & $884 / 1055(83 \%)$ & 0.0053 \\
\hline GDP-mannose-3",5"'-epimerase [Oryza sativa (japonica cultivar-group)] & BAD66930.1 & 0.0 & $354 / 378(93 \%)$ & 0.0072 \\
\hline Multi-copper oxidase type I family protein [Arabidopsis thaliana] & NP_177743.1 & 0.0 & $447 / 526(84 \%)$ & 0.0372 \\
\hline Putative cellulose synthase [Arabidopsis thaliana $]$ & AAC25936.1 & $\mathrm{e}^{-138}$ & $122 / 191(63 \%)$ & 0.0372 \\
\hline S-adenosylmethionine decarboxylase [Citrofortunella mitis] & AAM44307.1 & 0.0 & $353 / 361(97 \%)$ & 0.0000 \\
\hline Pectinesterase [Citrus sinensis] & AAB57670.1 & 0.0 & $576 / 584(98 \%)$ & 0.0291 \\
\hline Granule-bound starch synthase Ib precursor [Phaseolus vulgaris] & BAC76613.1 & 0.0 & $459 / 620(74 \%)$ & 0.0009 \\
\hline Triosephosphate isomerase [Petunia $x$ hybrida] & CAA58230.1 & $\mathrm{e}^{-117}$ & $206 / 254(81 \%)$ & 0.0372 \\
\hline Myo-inositol-1-phosphate synthase [Nicotiana paniculata] & BAA84084.1 & 0.0 & $480 / 510(94 \%)$ & 0.0000 \\
\hline Protoporphyrin IX:Mg Chelatase [Antirrhinum majus] & CAA51664.1 & 0.0 & $970 / 1071(90 \%)$ & 0.0004 \\
\hline Unknown protein [Arabidopsis thaliana] & AAL07213.1 & 0.0 & $326 / 458(71 \%)$ & 0.0001 \\
\hline SAM:phospho-ethanolamine N-methyltransferase $[$ Arabidopsis thaliana $]=$ & AAG41121.1 & 0.0 & $404 / 483(83 \%)$ & 0.0402 \\
\hline Palmitoyl-acyl carrier protein thioesterase [Gossypium hirsutum] & AAF02215.1 & $\mathrm{e}^{-177}$ & $317 / 418(75 \%)$ & 0.0372 \\
\hline Isoflavone reductase related protein [Pyrus communis] & AAC24001.1 & $\mathrm{e}^{-146}$ & $254 / 308(82 \%)$ & 0.0164 \\
\hline S-adenosyl-L-methionine synthetase [Elaeagnus umbellata] & AAK29409.1 & 0.0 & $374 / 393(95 \%)$ & 0.0009 \\
\hline Cobalamin-independent methionine synthase [Arabidopsis thaliana] & BAB11226.1 & 0.0 & $693 / 765(90 \%)$ & 0.0149 \\
\hline Chloroplast latex aldolase-like protein [Manihot esculenta] & AAV74407.1 & $\mathrm{e}^{-127}$ & $233 / 255(91 \%)$ & 0.0002 \\
\hline Terpene synthase [Vitis vinifera] & AAS66357.1 & $\mathrm{e}^{-160}$ & $279 / 563(49 \%)$ & 0.0048 \\
\hline Hydroxycinnamoyl transferase [Nicotiana tabacum] & CAD47830.1 & $\mathrm{e}^{-120}$ & $215 / 434(49 \%)$ & 0.0247 \\
\hline S-adenosyl-L-methionine:delta24-sterol-C-methyltransferase & AAB04057.1 & $\mathrm{e}^{-160}$ & $274 / 340(80 \%)$ & 0.0164 \\
\hline
\end{tabular}


Table 2 (cont.)

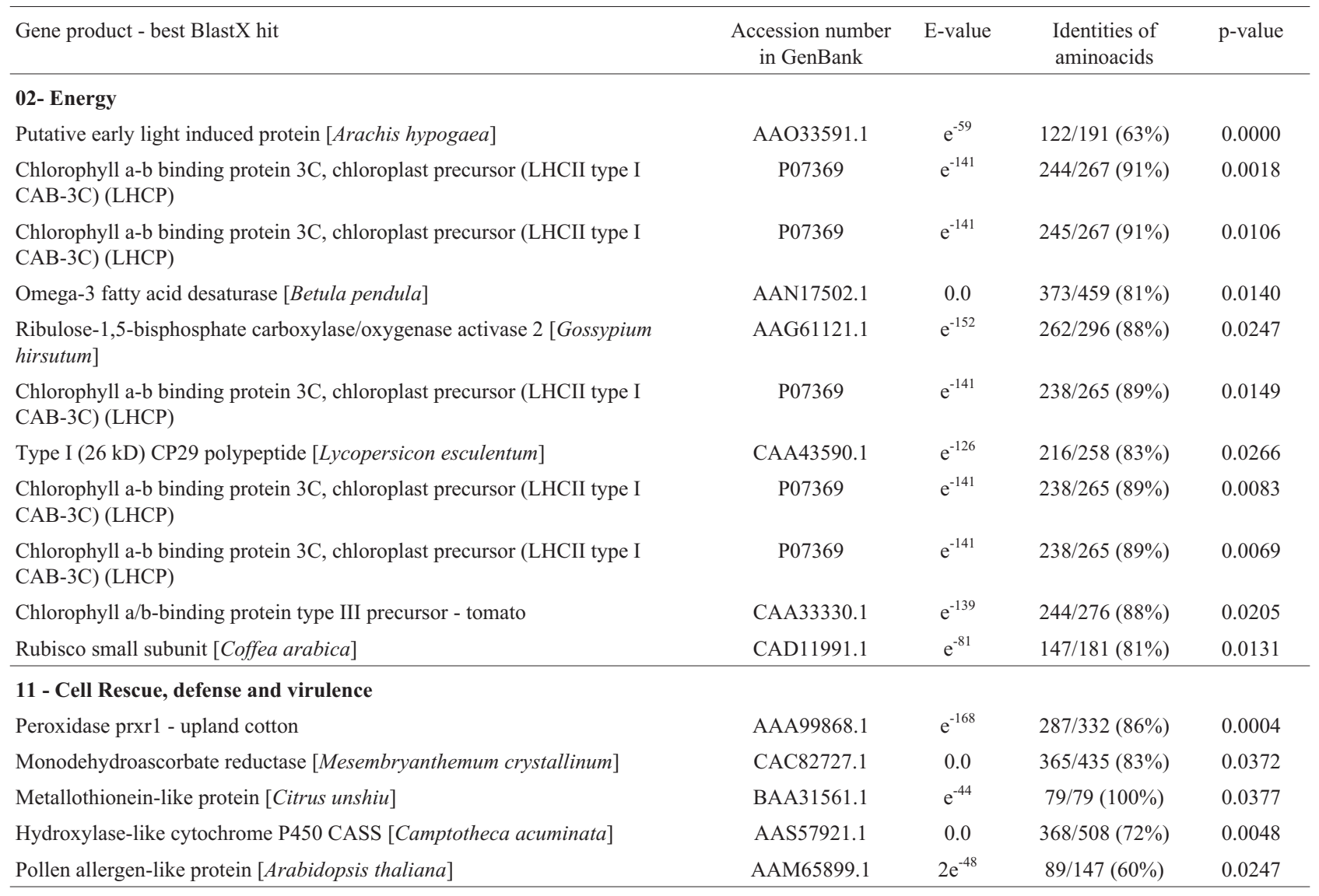

It remains clear that, even though interesting differential gene expression was observed between the two libraries regarding traditional biotic stress response, it is not yet sufficient to explain the main changes observed in sweet orange infected with CiLV-C. In fact, other genes within the MIPS FunCats of energy and metabolism seem to play more relevant roles in such compatible interaction, and will be discussed below.

\section{Energy and metabolism}

Nineteen differentially expressed TCs were classified within the MIPS energy category, with clear evidence of reduction in aerobic respiration in challenged sweet orange plants when compared to the non-challenged ones. In addition to a TC that codes for rubisco, other transcripts involved in aerobic respiration were mostly repressed by the pathogen, most of them coding for chlorophyll $\mathrm{a} / \mathrm{b}$ binding proteins (Table 2). Several studies have been conducted on the influence of viral diseases in host respiration rate. Hull (2002) summarizes these data stating that, for host-virus combinations where necrosis does not occur, the respiration rate starts to increase, often even before the appearance of symptoms, and continues rising as disease develops. In chronically infected plants, respiration is normally lower than normal, and sometimes unchanged. In host-virus inter- actions characterized by the appearance of necrotic local lesions, the respiration rate increases as necrosis develops.

These results are contrary to our data, which suggest a reduction in respiration rate during citrus-CiLV-C interaction. However, it is important to take into consideration that, even though the virus induces necrotic local lesions in sweet orange, the samples for the library construction were collected $48 \mathrm{~h}$ after inoculation, several weeks prior to the appearance of symptoms. It cannot be discarded that the respiration rate may increase as necrosis develops, as often observed in other combinations. It should also be noted that there was no evidence to support the hypothesis that citrus response to leprosis would be similar to that of HR. If the viral particle is not recognized by the host plant, a compatible interaction - which favors the virus - is established (Hammond-Kosack and Jones, 2000; Stange, 2006). In an incompatible reaction, development of the receptor-ligand complex triggers a cascade of transduction signals that ultimately leads to the HR response. This response is a local reaction characterized by programmed cell death (PCD) at the infection site (Heath, 2000). Importantly, during HR, reactive oxygen species are produced (Lamb and Dixon, 1997), callose (Shimomura and Dijkstra, 1975) and lignin are synthesized, the levels of salicylic acid increase (Naylor et al., 1998) and pathogenesis related proteins are produced 
(Yalpani et al., 1991). As a result, plants limit the short and long-distance movement of the pathogen (Stange, 2006; Guidetti-Gonzalez et al., this issue).

As will become clearer throughout this paper, we found several major differences between the molecular responses normally associated with typical HR induced by viruses in an incompatible interaction and the necrotic local lesion caused by CiLV-C in this compatible combination.

Interestingly, out of the 54 differentially expressed TCs automatically classified into the MIPS metabolism category (28 induced and 26 repressed; Table 2), several of their putative products are involved in the generation of precursor metabolites and energy and are related to photosynthesis and respiration. It was possible to observe a clear repression in genes that code for key enzymes involved in photorespiration, such as glycine hydroxymethyltransferase/serine hydroxymethyltransferase (SHMT), glycine decarboxylase, and alanine: glyoxylate aminotransferase (Taylor et al., 2002; Vol et al., 2006). These data suggest that even before the appearance of the typical chlorotic and necrotic symptoms of leprosis, genes involved in respiration are repressed. It strengthens the hypothesis that the response of citrus to CiLV-C is different from that observed in other hosts that develop necrotic local lesion when challenged with a viral agent. Altogether, this suggests that host-leprosis interaction presents more similarities with the initial steps of infection of other compatible plant-virus interactions (Hull, 2002).

Repression in gene expression was also observed for some transcripts that code for the key chlorophyll synthesis enzymes protoporphyrin IX magnesium chelatase and glutamyl-tRNA reductase (GluTR) suggesting that, as expected, the presence of the virus has influence on photosynthesis as well, even before the appearance of macroscopic symptoms (Van Kooten et al., 1990).

In fact, in a compatible host-pathogen interaction, studying the up-regulated genes is very important, but a careful review of repressed ones can be relevant as well. The repressed genes can lead to important cues to understanding viral interference in plant metabolism in order to establish an adequate environment for the development of the disease. Repression of genes involved in chlorophyll synthesis has been found not only in plants undergoing biotic, but also abiotic - such as cold - stress (Mohanty et al., 2006). Similarly, it has been shown that enzymes involved in the photorespiratory pathway, such as SHMT, may play an important role in the response not only to biotic, but also to abiotic stress (Moreno et al., 2005). The authors found that a recessive mutation in the Arabidopsis shmt1 gene (shmt1-1) causes aberrant regulation of cell death resulting in chlorotic and necrotic lesion formation under a variety of environmental conditions. Hence, the repression of the shmt gene in the compatible citrus-CiLV interaction studied may be involved in the intensification of the typical leprosis symptoms observed.
Tentative consensi comprising transcripts involved in saturated fatty acid synthesis, methionine metabolism, and biosynthesis of phenylpropanoids and terpenes were also found to be repressed in our analyses. Four genes belonging to the latter groups stand out: phenylalanine-ammonia lyase $(p a l)$, isoflavone reductase (ifr) and hydroxycinnamoyl transferase $(h c t)$, related to phenylpropanoid biosynthesis, and terpene synthase (tps), which encodes the primary enzyme in the formation of low-molecular-weight terpene metabolites. The pal gene codes for the PAL protein, the first enzyme of the phenylpropanoid biosynthesis, involved in an array of functions, from synthesis of flavonoids to phytoalexins, lignin, and other important secondary metabolites associated with plant development, structure and defense (Klessig et al., 2000). One of the major roles of the isoflavones is to provide the disease resistance response by inducing the formation of the defense compounds against phytopathogenic microorganisms. The enzyme IFR catalyzes a NADPH-dependent reduction and acts in the biosynthesis of important and related phenylpropanoid-derived plant defense proteins (Dixon and Steele, 1999; Verica et al., 2004). Lignins are extremely resistant to microbial degradation and are often induced at sites of pathogen infection, playing important roles in cell wall reinforcement and, consequently, increased defense response against infection (Lange et al., 1995; Kawasaki et al., 2006). The HCT enzyme is an acyltransferase that is potentially implicated in the pathway both upstream and downstream of the 3-hydroxylation step in lignin biosynthesis. The induction of lignin synthesis or lignin-related genes after virus challenge has been reported in incompatible interactions in herbaceous plants (Jaeck et al., 1992) and, recently, in citrus (Cristofani-Yaly et al., this issue). Since in both cases lignification seems to help prevent viral infection, it is not surprising to observe that in the compatible citrus-CiLV-C combination, we found evidence for repression of lignin production.

Terpene metabolites are important compounds in direct defense against microbes and insects (Loreto et al., 2004), and several tps genes are induced in leaves by herbivore attack (Bohlmann et al., 1997; Steele et al., 1998). Similarly, the repression of tps found in our analyses suggests that these compounds did not play a relevant role in increasing defense against leprosis. However, our data do not explain why tps was repressed, and therefore should be addressed in further studies.

Three other TCs that had their expression repressed after challenge by CiLV-C harbored genes involved in abiotic stress response. One of them codes for an inositol3-phosphate synthase (Myo-inositol-1-phosphate synthase, MIPS), for which expression has been reported as either reduced (Chun et al., 2003) or increased (Buchanan et al., 2005) under salt and osmotic stress, for sesame and sorghum, respectively. The second transcript codes for phosphoethanolamine N-methyltransferase (PEAMT), an 
important enzyme for the synthesis of glycinebetaine (betaine). Betaine is a compatible solute that accumulates in large amounts in certain plants and which seems to play a role in the protection from salt stress (Tabuchi et al., 2005). Finally, a third repressed transcript codes for S-adenosylmethionine decarboxylase (SAMDC), which is involved in increased resistance or tolerance to numerous abiotic stresses, since it is a key enzyme in polyamine (PA) biosynthesis. In a recent paper, Wi et al. (2006) showed that the overexpression of the carnation SAMDC gene generated a broad-spectrum tolerance to abiotic stressors in transgenic tobacco plants. The authors found that the transgenic plants had an increased net photosynthetic rate and showed attenuated stress-induced damage and the appearance of yellowing and chlorophyll degradation symptom, suggesting that PAs may have pivotal importance in stress tolerance in plants. Interestingly, Hao et al. (2005) isolated and cloned two SADMC cDNAs from apple plants and showed that only one of them was actually involved in stress responses, while the other was likely to be involved in fruit development and cell growth. It is interesting that at least three transcripts associated with abiotic stress responses were repressed in the compatible interaction studies; however, whether or not they play any role in the susceptible response of sweet orange to leprosis remains to be tested.

Another repressed TC was composed of reads that code for a putative acyl CoA synthetase (LCAS2), which has roles in lipid synthesis, fatty acid catabolism, and the transport of fatty acids between subcellular compartments. It also seems to be involved in normal cuticle development in Arabidopsis and lacs2 mutant phenotype causes, among other things, reduced leaf size and plant growth (Schnurr et al., 2004). Interestingly, two TCs harboring genes that code for proteins related to lipid metabolism were found to be induced in the same sweet orange library. One of them, an amino-alcohol phosphotransferase, is involved in the biosynthesis of phospholipids, while the other, a thiolase, is involved in the degradation of fatty acids. Lipids are connected to the plant defense response against biotrophic fungi, bacteria, and viruses (Thomma et al., 2001; Murphy and Carr, 2002) through their potential action as signaling molecules (Laxalt and Munnik, 2002; Maldonado et al., 2002). In fact, production of fatty acids is an early step in cell death caused by oxidative burst (Montillet et al., 2005) that will result in HR. Our data demonstrated not only a repression in the synthesis of fatty acids, but also an increase in its degradation, suggesting that fatty acid metabolism is important to the susceptibility of Pêra sweet orange to leprosis. Also, this result clearly points out that the host responses to CiLV-C significantly differ from those observed during HR.

Two TCs that had their expression induced after CiLV-C challenge were composed of reads that encode the enzymes pectinesterase and cellulase, related to the degra- dation of pectin and cellulose, respectively. Since they are the main components of the plant cell wall, it seems evident that, even prior to symptom appearance, there is a disruption of the cell physical structure, which will ultimately lead to cell collapse and death. Interestingly, not only cellulose gene expression was induced, but also a cellulose synthase gene was found to be repressed in the library constructed from inoculated leaves, suggesting a role in the symptoms observed.

As expected, several other TCs harbored transcripts involved in carbohydrate metabolism were found to be differentially expressed between the two libraries. Two of them, that code for a GDP-mannose 3',5'-epimerase and a triosephosphate isomerase, were repressed. GDP-man 3',5'-epimerase is a late methyl jasmonate-responsive enzyme that helps control the carbon flux into the vitamin $\mathrm{C}$ pathway in response to the redox state of the cell, stress conditions, and GDP-sugar demand for cell wall/glycoprotein biosynthesis (Wolucka and Van Montagu, 2002; Wolucka et al., 2005). Triosephosphate isomerase, an enzyme in the glycolysis pathway, is also involved in stress response, and reduction in its expression is reported in plants after abiotic or biotic stress conditions (Riccardi et al., 1998; Morris and Djordjevic, 2001).

Three TCs composed of transcripts involved in carbohydrate metabolism were found to be induced in the CiLVC-inoculated library, one encoding a sucrose synthase, another one, a glucose-6-phosphate isomerase, and a third one, a mannose pyrophosphorilase. Numerous reports have indicated that carbohydrate metabolism in the source leaf is influenced by viral infection (Tecsi et al., 1994a, 1994b, 1996). Infected source leaves are usually characterized by a decrease in the concentration of soluble sugars, and often starch accumulation (Goodman et al., 1986; Fraser, 1987). Changes in the capacities of enzymes in various metabolic pathways have been measured during infection of cotyledons of Cucurbita pepo L. with Cucumber mosaic virus (CMV). CMV infection significantly altered carbohydrate metabolism, with a sharp increase in the concentrations of soluble sugars observed in the infected leaves. These changes were associated with a decrease in leaf starch content. An earlier study indicated an increase in reducing sugars and a reduction in starch content due to CMV-induced higher starch hydrolase and lower ADP-Glc pyrophosphorylase activities (Tecsi et al., 1994b). It has been proposed that the inhibition of starch accumulation and/or starch degradation is probably due to the increased demand for soluble sugars required to maintain the high respiration rate (Tecsi et al., 1996; Shalitin and Wolf, 2000).

In our data analysis we not only found an increase in the expression of transcripts that code for enzymes involved in synthesis of soluble sugars, but also in the expression of transcripts related to starch degradation. Interestingly, it has recently been shown, through histological studies using light microscopy, that there is a clear reduc- 
tion in starch accumulation in the epidermis of sweet orange leaves and stems symptomatic for leprosis (Marques et al., 2005), corroborating our gene expression data and suggesting a common response to viruses that invade systemically or cause only local lesions in their hosts.

\section{Final Considerations}

Our study showed that CiLV-C infection induced immediate and subsequent changes in host gene expression and that the infection can potentially give advance signaling of an imminent infection. Even though there was clear variation in the expression of genes involved in cell rescue, defense and virulence, the most relevant molecular changes observed seem to have occurred in the MIPS energy and metabolism categories. It can be understood as a new data, since it is a compatible interaction, different than most of the other studies done on plant-pathogen combinations.

In addition, the fact that CiLV-C causes only chlorotic and necrotic local lesions in susceptible hosts, and never invades them systemically, has raised questions regarding whether or not the symptoms could be a variation of the HR observed in viral incompatible interactions. However, our data strongly indicate that the two responses are very different at the molecular level and hence, the manifestation of leprosis symptoms should not be considered HR.

\section{Acknowledgments}

The authors would like to thank Carolina M. Rodrigues, Kleber M. Borges, Juliana M. de Souza, and Silvia de O. Dorta for technical assistance in sequencing the libraries, M.Sc. Marcelo Reis for the bioinformatic assistance, and $\mathrm{CNPq} /$ Millennium Institute (62.0054/01-8) and FAPESP (04/10511-3) for financially supporting this work.

\section{References}

Audic S and Claverie JM (1997) The significance of digital gene expression profiles. Genome Res 7:986-995.

Bastianel M, Freitas-Astúa J, Kitajima EW and Machado MA (2006a) The citrus leprosis pathosystem. Summa Phytopathol 32:211-220.

Bastianel M, Oliveira AC, Cristofani M, Guerreiro Filho O, Freitas-Astúa J, Rodrigues V, Astúa-Monge G and Machado MA (2006b) Inheritance and heritability of resistance to citrus leprosis. Phytopathology 96:1092-1096.

Boteon M and Neves EM (2005) Citricultura brasileira: Aspectos econômicos. In: Mattos Jr D, De Negri JD, Pio RM and Pompeu Jr J (eds) Citros. Instituto Agronômico e Fundag, Campinas, pp 21.

Bohlmann J, Steele CL and Croteau R (1997) Monoterpene synthases from grand fir (Abies grandis) cDNA isolation, characterization, and functional expression of myrcene synthase, (2)-(4S)-limonene synthase, and (2)-(1S,5S)-pinene synthase. J Biol Chem 272:21784-21792.

Buchanan CD, Lim S, Salzman RA, Kagiampakis I, Morishige DT, Weers BD, Klein RR, Pratt LH, Cordonnier-Pratt MM, Klein PE, et al. (2005) Sorghum bicolor's transcriptome re- sponse to dehydration, high salinity and ABA. Plant Mol Biol 58:699-720.

Chiasson D, Ekengren SK, Martin GB, Dobney SL and Snedden WA (2005) Calmodulin-like proteins from Arabidopsis and tomato are involved in host defense against Pseudomonas syringae pv. tomato. Plant Mol Biol 58:887-897.

Chun JA, Jin UH, Lee JW, Yi YB, Hyung NI, Kang MH, Pyee JH, Suh MC, Kang CW, Seo HY, et al. (2003) Isolation and characterization of a myo-inositol 1-phosphate synthase cDNA from developing sesame (Sesamum indicum L.) seeds: Functional and differential expression, and salt-induced transcription during germination. Planta 216:874-880.

Dixon RA and Steele CL (1999) Flavonoids and isoflavonoids - A gold mine for metabolic engineering. Trends Plant Sci 4:394-400.

Doke N, Miura Y, Sanchez LM, Park HJ, Noritake T, Yoshioka H and Kawakita K (1996) The oxidative burst protects plants against pathogen attack: Mechanism and role as an emergency signal for plant bio-defence - A review. Gene 79:4551.

Fraser RSS (1987) Biochemistry of Virus-Infected Plants. Research Studies Press, Letchworth, 259 pp.

Gatehouse AMR, Davison GM, Stewart JN, Gatehouse LN, Kumar A, Geoghegan IE, Birch ANE and Gatehouse JA (1999) Concanavalin A inhibits development of tomato moth (Lacanobia oleracea) and peach-potato aphid (Myzus persicae) when expressed in transgenic potato plants. Mol Breed 5:153-165.

Grant JJ and Loake GJ (2000) Role of reactive oxygen intermediates and cognate redox signaling in disease resistance. Plant Physiol 124:21-30.

Goodman RN, Király Z and Wood KR (1986) The Biochemistry and Physiology of Plant Disease. University of Missouri Press, Columbia, 433 p.

Hao YJ, Zhang Z, Kitashiba H, Honda C, Ubi B, Kita M and Moriguchi T (2005) Molecular cloning and functional characterization of two apple S-adenosylmethionine decarboxylase genes and their different expression in fruit development, cell growth and stress responses. Gene 350:41-50.

Hammond-Kosack K and Jones JDG (2000) Responses to plant pathogens. In: Buchanan BB, Gruíssem $\mathrm{W}$ and Jones RL (eds) Biochemistry and Molecular Biology of Plants. American Society of Plant Physiology, Rockville, pp 1102-1156.

Heath MC (2000) Hypersensitive response-related death. Plant Mol Biol 44:321-334.

Huang X and Madan A (1999) CAP3: A DNA sequence assembly program. Genome Res 9:868-877.

Huang Z, Yeakley JM, Garcia EW, Holdridge JD, Fan JB and Whitham SA (2005) Salicylic acid-dependent expression of host genes in compatible Arabidopsis-virus interactions. Plant Physiol 137:1147-1159.

Hull R (2002) Matthews' Plant Virology. $4^{\text {th }}$ edition. Academic Press, Orlando, $1001 \mathrm{pp}$.

Jaeck E, Dumas B, Geoffroy P, Favet N, Inze D, van Montagu M, Fritig B and Legrand M (1992) Regulation of enzymes involved in lignin biosynthesis: Induction of O-methyltransferase rnRNAs during the hypersensitive reaction of tobacco to Tobacco mosaic virus. Mol Plant-Microbe Interact 5:294-300.

Kawasaki T, Koita H, Nakatsubo T, Hasegawa K, Wakabayashi K, Takahashi H, Umemura K, Umezawa T and Shimamoto 
K (2006) Cinnamoyl-CoA reductase, a key enzyme in lignin biosynthesis, is an effector of small GTPase Rac in defense signaling in rice. Proc Natl Acad Sci USA 103:230-235.

Klessig DF, Durner J, Noad R, Navarre DA, Wendehenne D, Kumar D, Zhou JM, Shah J, Zhang S, Kachroo P, et al. (2000) Nitric oxide and salicylic acid signaling in plant defenses. Proc Natl Acad Sci USA 97:8849-8855.

Kim YC, Kim SY, Paek KH, Choi D and Park JM (2006) Suppression of CaCYP1, a novel cytochrome P450 gene, compromises the basal pathogen defense response of pepper plants. Biochem Biophys Res Commun 345:638-645.

Lamb C and Dixon RA (1997) The oxidative burst in plant disease resistance. Annu Rev Plant Physiol Plant Mol Biol 48:251275.

Laxalt AM and Munnik T (2002) Phospholipid signaling in plant defense. Curr Opin Plant Biol 5:332-338.

Lange BM, Lapierre C and Sandermann Jr H (1995) Elicitorinduced spruce stress lignin (structural similarity to early developmental lignins). Plant Physiol 108:1277-1287.

Locali EC, Freitas-Astúa J, Souza AA, Takita MA, Astua-Monge G, Antonioli-Luizon R, Kitajima EW and Machado MA (2003) Development of a molecular tool for the diagnosis of leprosis, a major threat to the citrus production in the Americas. Plant Dis 87:1317-1321.

Locali-Fabris EC, Freitas-Astúa J, Souza AA, Takita MA, AstúaMonge G, Antoniolli-Luizon R, Rodrigues V, Targon MLPN and Machado MA (2006) Complete nucleotide sequence, genomic organization and phylogenetic analysis of Citrus leprosis virus cytoplasmic type. J Gen Virol 87:2721-2729.

Loreto F, Pinelli P, Manes F and Kollist H (2004) Impact of ozone on monoterpene emissions and evidence for an isoprene-like antioxidant action of monoterpenes emitted by Quercus ilex leaves. Tree Physiol 24:361-367.

Maldonado AM, Doerner P, Dixonk RA, Lamb CJ and Cameron RK (2002) A putative lipid transfer protein involved in systemic resistance signalling in Arabidopsis. Nature 419:399403.

Marques JPR, Appezzato-da-Gloria B, Gomes RT, Freitas-Astua J and Kitajima EW (2005) Análise anatômica e ultra-estrutural das lesões caulinares causadas pela leprose em Citrus sinensis (L) Osbeck 'Pera'. In: $56^{\circ}$ Congresso Nacional de Botânica, Curitiba. P09-17:395.

Maule A, Leh V and Lederer C (2002) The dialogue between viruses and hosts in compatible interactions. Curr Opin Plant Biol 5:279-284.

Mohanty S, Grimm B and Tripathy BC (2006) Light and dark modulation of chlorophyll biosynthetic genes in response to temperature. Planta 224:692-699.

Moller SG and Chua N-H (1999) Interactions and intersections of plant signaling pathways. J Mol Biol 293:219-234.

Montillet J-L, Chamnongpol S, Rustérucci C, Dat J, Van de Cotte B, Agnel J-P, Battesti C, Inzé D, Van Breusegem F and Triantaphylidès $\mathrm{C}$ (2005) Fatty acid hydroperoxides and $\mathrm{H}_{2} \mathrm{O}_{2}$ in the execution of hypersensitive cell death in tobacco leaves. Plant Physiol 138:1516-1526.

Moreno JI, Martin R and Castresana C (2005) Arabidopsis SHMT1, a serine hydroxymethyltransferase that functions in the photorespiratory pathway influences resistance to biotic and abiotic stress. Plant J 41:451-63.
Morris AC and Djordjevic MA (2001) Proteome analysis of cultivar-specific interactions between Rhizobium leguminosarum biovar trifolii and subterranean clover cultivar Woogenellup. Electrophoresis 22:586-598.

Murphy AM and Carr JP (2002) Salicylic acid has cell-specific effects on Tobacco mosaic virus replication and cell-to-cell movement. Plant Physiol 128:552-563.

Naylor M, Murphy AM, Berry JO and Carr JP (1998) Salicylic acid can induce resistance to plant virus movement. Molec Plant-Microbe Interact 11:860-868.

Novelli VM, Freitas-Astúa J, Arrivabem F, Locali EC, Hilf ME, Gottwald TR and Machado MA (2005) O ácaro vetor da leprose dos citros (Brevipalpus phoenicis) e a interação com endossimbiontes CLO (Cytophaga-Like-Organism). Laranja 26:273-289.

Pascon RC, Kitajima JP, Breton MC, Assumpção L, Greggio C, Zanca AS, Okura VK, Alegria MC, Camargo ME, Silva GGC, et al. (2006) The complete nucleotide sequence and genomic organization of Citrus leprosis associated virus, cytoplasmatic type (CiLV-C). Virus Genes 32:289-298.

Riccardi F, Gazeau P, de Vienne D and Zivy M (1998) Protein changes in response to progressive water deficit in maize. Quantitative variation and polypeptide identification. Plant Physiol 117:1253-1263.

Romano PGN, Horton P and Gray JE (2004) The Arabidopsis cyclophilin gene family. Plant Physiol 134:1268-1282.

Shalitin D and Wolf S (2000) Cucumber mosaic virus infection affects sugar transport in melon plants. Plant Physiol 123:597-604.

Shimomura T and Dijkstra J (1975) The occurrence of callose during the process of local lesion formation. Neth J Plant Pathol 81:107-121.

Schnurr J, Shockey J and Browse J (2004) The acyl-CoA synthetase encoded by LACS2 is essential for normal cuticle development in Arabidopsis. Plant Cell 16:629-642.

Steele CL, Katoh S, Bohlmann J and Croteau R (1998) Regulation of oleoresinosis in grand fir (Abies grandis): Differential transcriptional control of monoterpene, sesquiterpene, and diterpene synthase genes in response to wounding. Plant Physiol 116:1497-1504.

Stange C (2006) Plant-virus interactions during the infective process. Cien Inv Agr 33:1-18.

Tabuchi T, Kawaguchi Y, Azuma T, Nanmori T and Yasuda T (2005) Similar regulation patterns of choline monooxygenase, phosphoethanolamine N-methyltransferase and S-adenosyl-L-methionine synthetase in leaves of the halophyte Atriplex nummularia L. Plant Cell Physiol 46:505-513.

Taylor NL, Day DA and Millar AH (2002) Environmental stress causes oxidative damage to plant mitochondria leading to inhibition of glycine decarboxylase. J Biol Chem 277:42663-42668.

Tecsi LI, Maule AJ, Smith AM and Leegood RC (1994a) Complex, localised changes in $\mathrm{CO}$, assimilation and starch content associated with the susceptible interaction between $\mathrm{Cu}$ cumber mosaic virus and a cucurbit host. Plant J 5:837-847.

Tecsi LI, Maule AJ, Smith AM and Leegood RC (1994b) Metabolic alterations in cotyledons of Cucurbita pepo infected by Cucumber mosaic virus. J Exp Bot 45:1541-1551.

Tecsi LI, Smith AM, Maule AJ and Leegood RC (1996) A spatial analysis of physiological changes associated with infection 
of cotyledons of marrow plants with Cucumber mosaic virus. Plant Physiol 111:975-985.

Thomma B, Tierens KFM, Pennickx IAMA, Mauch-Mani B, Broekaert WF and Cammue BPA (2001) Different microorganisms differentially induce Arabidopsis disease response pathways. Plant Physiol Biochem 39:673-680.

Van Kooten O, Meurs C and Van Loon LC (1990) Photosynthetic electron transport in tobacco leaves infected with Tobacco mosaic virus. Physiol Plant 80:446-452.

Verica JA, Maximova SN, Strem MD, Carlson JE, Bailey BA and Guiltinan MJ (2004) Isolation of ESTs from cacao (Theobroma cacao L.) leaves treated with inducers of the defense response. Plant Cell Rep 23:404-413.

Vol LM, Jamai A, Renne P, Voll H, McClung CR and Weber AP (2006) The photorespiratory Arabidopsis shm1 mutant is deficient in SHM1. Plant Physiol 140:59-66.

Wi SJ, Kim WT and Park KY (2006) Overexpression of carnation S-adenosylmethionine decarboxylase gene generates a broad-spectrum tolerance to abiotic stresses in transgenic tobacco plants. Plant Cell Rep 25:1111-1121.
Wolucka BA, Goossens A and Inze D (2005) Methyl jasmonate stimulates the de novo biosynthesis of vitamin $\mathrm{C}$ in plant cell suspensions. J Exp Bot 56:2527-2538.

Wolucka BA and Van Montagu M (2002) GDP-mannose 3',5'epimerase forms GDP-L-gulose, a putative intermediate for the de novo biosynthesis of vitamin $\mathrm{C}$ in plants. J Biol Chem 278:47483-47490.

Yalpani N, Silverman P, Wilson TMA, Kleier DA and Raskin I (1991) Salicylic acid is a systemic signal and an inducer of pathogenesis-related proteins in virus-infected tobacco. Plant Cell 3:809-818.

\section{Internet Resources}

GenBank, http://www.ncbi.nlm.nih.gov/BLAST/ (May 3, 2006). Arabidopsis Genome Initiative, http://www.arabidopsis.org (May 5, 2006).

Kyoto Encyclopedia of Genes and Genomes (KEGG), http:// www.genome.jp/kegg/ (May 11, 2006).

Munich Center for Proteins and Sequences Functional Categories (MIPS), http://mips.gsf.de (May 15, 2006).

Associate Editor: Ivan de Godoy Maia 